\title{
Prevalence of dementia in Al-Quseir city, Red Sea Governorate, Egypt [Corrigendum]
}

El Tallawy HN, Farghly WM, Badry R, et al. Clinical Interventions in Aging. 2014;9:9-14.

On page 13, before the Disclosure statement the following section was omitted.

\section{Acknowledgment}

We acknowledge LundBeck Pharmaceutical company, Middle East for their support in conducting this research.

\section{Publish your work in this journal}

Clinical Interventions in Aging is an international, peer-reviewed journal focusing on evidence-based reports on the value or lack thereof of treatments intended to prevent or delay the onset of maladaptive correlates of aging in human beings. This journal is indexed on PubMed Central, MedLine, the American Chemical Society's 'Chemical Abstracts
Service' (CAS), Scopus and the Elsevier Bibliographic databases. The manuscript management system is completely online and includes a very quick and fair peer-review system, which is all easy to use. Visit http://www.dovepress.com/testimonials.php to read real quotes from published authors. 